\title{
The Symphonichnost (Symphonic Nature) of Music Studies by V.V. Medushevsky
}

\author{
Galima Lukina \\ Russian State Specialized Arts Academy \\ Moscow, Russia \\ e-mail: galimalukina@yandex.ru
}

\begin{abstract}
The article is dedicated to the comprehension of the scientific works by V.V. Medushevsky, famous Russian musicologist, teacher, Doctor of Arts, Professor of Moscow P.I. Tchaikovsky Conservatory. The author shows that through his numerous works Medushevsky aspires to the implementation of the experience of Christian interpretation of the music nature and its most fundamental laws.
\end{abstract}

Keywords-music studies; the spiritual meaning of music; V.V. Medushevsky; symphonichnost; symphonic nature; intonation; intonational analysis

\section{INTRODUCTION}

At the present time of the postmodernism "sunset" evaluative look at the phenomena of art is extremely important. V.V. Medushevsky offers a certain system of theoretical and methodological points, determined by Christian worldview. The musicology interpreted by him as the science of "beautiful in sounds", of the spiritual meaning of music, "emanative by the beauty of sound organization" $[7,64]$.

At the heart of the study by Medushevsky there is an essentially-ontological understanding of music as intonational incarnation of the Logos of being. The music teaches Medushevsky - "initially just embodies, not only symbolizes the semantic energy" [8, 204]. This power gave birth to a serious art, building "horizontal as the form of the spiritual vertical expression" [6]. It is life-giving energy, soul inspired by the glory of God "flowing from all sides of [beautiful] music and its smallest parts" [ibid]. Thus the analysis in the study by Medushevsky is based on the intonational hearing, i.e., hearing of the music "in the simultaneous embracing of all its components, disclosing to the ear" [ibid].

Such a reference point for integrity in the approach to the analysis of the music piece shows involvement of the study by Medushevsky in the tradition of native musicology.

\section{INTONATIONAL ANALYSIS OF MEDUSHEVSKY FROM} THE STANDPOINT OF THE NATIVE MUSICOLOGY TRADITIONS

In the book "Intonational form of music" Medushevsky undertook a detailed and in-depth study of Asafiev's message about intonation as sound-semantic substance of the music language. According to Medushevsky, intonation is "indissoluble unity of all sounding parties joined through energies of sense" [8, 260].

Medushevsky develops the ideas about the regularity of explication of the music piece and the form making principles by V.P. Bobrowsky, E.V. Nazaikinsky, V.P. Protopopov, S.S. Screbkov, B.L. Yavorsky.

Medushevsky continues the theory of integral analysis of the music pieces, which was founded by L.A. Mazel, I.J. Ryzhkin, V.A. Zuckerman and others. A common, similar in analytical methods for Medushevsky and for representatives of the integral analysis - is first of all analysis focusing on the opening of the music content; the idea of the convergence of theoretical musicology with humanities for understanding the content of a piece of music; integrity principle. Analytical strategy in their works is based on finding out as much as possible the full range of means of expression in the piece and their semantic interpretation.

However, it should be noted the difference of approaches. The ideologues of integral analysis understand art as "a form of social consciousness, reflection of "the most different phenomena of reality... In this case, in contrast to science, - as Lev Abramovich Mazel emphasizes, - the art essentially breaks the phenomena of reality "in the artistic image [5, 10-11].

The last one defined the convergence of theoretical musicology in the integral analysis primarily with aesthetics.

In the works by Medushevsky the musicology communications are greatly enhanced. The art understands as the artistic vision of the invisible. It is the essence of the intonational-ontological understanding of the world as one visible and invisible. Thus, the intonational and ontological method involves not only the artistic image reading but the ideas, the meaning of the music piece, what defined the integration of musicology and philosophy. Analysis of the musical piece understands as the form of the thought movement from observed details to the meaning, the idea that caused them to life. The history of the music shows us the historical depth of the intonational content, including simple emotions and true life of the spirit. The intonational approach allows perceiving the highest manifestation of spiritual aspiration in the masterpieces of classical music 
and other life-purpose orientation - the acquisition of earthly delights (such as pop music).

Philosophical "turn" in musicology is inherent to some works by Y.N. Kholopov for who the phenomenon of music is "the sphere of objectification of the spirit" [9, 67], "the natural extension of the world Creation" $[10,17]$. The basis of the Kholopov's studies, as rightly pointed by Larissa Valentinovna Kirillina, "was undoubtedly the PythagoreanPlatonic-Christian idea of God as the Creator - and above all, as the Creator of all beauty" [op. at 4, 16].

However, speaking of God, the Spirit, the Logos, the Creator of the world, Medushevsky is referring to the Christian God and therefore the essence of music and its analysis our scientist considers proceeding the Gospel revelations. It is this saving power - Medushevsky writes - "raised the greatest civilization on the earth". The beautiful music of Europe and Russia "is the Gospel tonally expressed" [6]. Therefore, the main "task" of a musical piece is to "raise the soul to heaven, send it to a spiritual orbit" [ibid]. However, the "music makes you feel not only the efforts of the rising to the divine "You", but also returned energies, the gospel of eternal life" [ibid].

Thus, easily and clear Medushevsky reminds the modern musicology about the interpretation of art as "a communion with God," as the symphonic harmony of Man and God.

Understanding of the music, born in a lively, real relationship of man with God and God with man, allows recovering of the interrupted connection between musicology and theology. Without theology, without its highest look at things the idea of correlation between music and society, people and the morality loses the contact with tradition - the tradition that "can give reliable guidance on spiritual issues, because it has religious roots (the same as in European culture as a whole, including philosophy and music) "[1, 48].

Theology helps to find the right words to musicology, which at times are so difficult to find, describing the ideological and imaginative music content of the great European and Russian composers.

\section{ONTOLOGICAL ASPIRATION OF MUSIC STUDIES BY V.V. MEDUSHEVSKY}

In the 90ies of the last century the time when native musicology was forced to go for atheistic science, "enlightened atheism", came to an end. The works by V.V. Medushevsky perceived as a breakthrough humanities to renewal, it can be said to "evangelical renewal" [3, 297], i.e., to the understanding of own freedom and conscience through the depth of own faith. The harmonious union of musicology and theology is born and it is aimed at understanding the very essence, the general meaning of art in a variety of musical intonations, forms, genres, styles in classical music. Ontological aspiration of music studies by V.V. Medushevsky to the completeness and integrity indicates the property that the Russian thinker Lev Platonovich Karsavin called the symphonichnost. This is a philosophical concept, and it is not related to the method and thematic invention in instrumental music. Its content is inseparable from the integrity — the feature of being, involving the harmony, that is, Symphony of the Creator and creation.

The symphonichnost of the scientist's thinking comes in looking at the seemingly well-known facts in the music art. But Medushevsky sheds new light on them; he returns them to the height of the traditions of Russian and European Christian culture. For example, in his new published textbook "The spiritual analysis of music" there are such chapters as: "A look at the sonata form by Christian anthropology", "The entelechy of romanticism", "Spiritual and functional logic of recapitulation forms", "Eternity and time in the feeling of sound", "On the heavenly unity of musical thinking", "Devotional "You" in secular music", etc.

During the analysis of musical masterpieces Medushevsky gives an explanation of the different areas of spiritual knowledge about the entire world and the man. A man, according to V.V. Zenkovsky, "is not a simple sum of the "body plus soul plus spirit"; if he is a living unity of all his powers and he lives one whole life, then it means that he always and everywhere is physical and spiritual" [2,211].

The symphonichnost is immanent to the study by Medushevsky at the level of understanding the integrity of musical intonation, understanding the form as dual-single integer; at the level of method that combines tonal analysis and Orthodox-ontological interpretation. In this free unity, affirming in the process of the analysis the identity of the integrity and the value of music, divine-human synergy as its last aim, the idea of unity appropriated to the Russian religious philosophy is refracted.

\section{CONCLUSION}

Thus, it can be argued that in his works Medushevsky not only continues the tradition of native musicology, but also makes it stronger through the unity with the tradition of Russian religious philosophy and, in general, the Christian theological thought.

\section{REFERENCES}

[1] Efimova I. V. O «dukhovoy muzyke» i o dukhovnosti v muzyke// Sb. Nauchnykh statey po mat. VIII Vserossiyskoy nauchno-prakticheskoy konferentsii «"Rodnaya zemlya" obraz i ideya russkoy kultury». Kursk, 2012. - P. 39-53.

[2] Zen'kovsky V.V. O soderzhanii ponyatiya «obraz Bozhiy» // Zen'kovsky V.V. Smysl pravoslavnoy kultury. M., 2007. P. $209-$ 215.

[3] Il'in I.A. Sobr. soch.: v 10 tomakh. T. 1. - M., 1993.

[4] Kirillina L.V. Philosophskie, esteticheskie i istoricheskie aspekty ucheniya J.N. Kholopova // Idei Идеи J.N. Kholopova v XXI veke. K 70-letiyu so dnya rozhdeniya. M., 2008. - P. 12-27.

[5] Mazel' L.A. Stroenie muzykalnogo proizvedeniya. M., 1979.

[6] Medushevsky V.V. Dukhovny analiz muzyki: uchebnoe posobie. M., 2014.

[7] Medushevsky V.V. Muzykovedenie // Sputnik uchitelya muzyki. M., 1993. P. 63-125. P. 64.

[8] Medushevsky V.V. Intonatsionnaya forma muzyki. — M., 1993

[9] Kholopov J.N. Vvedenie v muzykal'nuyu formu. - M., 2006. 
[10] Sator tenet opera rotas. Jury Nikolaevitch Kholopov i ego nauchnaya shkola (k 70-letiyu so dnya rozhdeniya). - M., 2003. 